Центр воєнно-стратегічних досліджень Національного університету оборони України імені Івана Черняховського, Київ

\title{
Забезпечення доступності інформації у центрі обробки даних військового призначення на основі балансу продуктивності системи
}

\begin{abstract}
Резюме. Досліджується проблема забезпечення доступності інформації у розподіленому мережевому середовищі Центру обробки даних військового призначення. Визначено структуру та розроблено опис процесу функціонування інформаційної системи, призначеної для розподіленого виконання завдань. Запропоновано методику оцінювання продуктивності елементів розподіленої інформаційної системи на основі побудови часового профілю.
\end{abstract}

Ключові слова: центр обробки даних; розподілена інформаційна система; часовий профіль; послідовний виконавець; пропускна спроможність; час відгуку системи.

Постановка проблеми. Інформатизація Збройних Сил України передбачає створення інформаційної інфраструктури та впровадження елементів єдиної автоматизованої системи управління Збройних Сил України [1]. Програмноапаратною основою та головною складовою інформаційної інфраструктури Міністерства оборони України мають стати центри обробки даних (ЦОД). Сучасний ЦОД - це складний, розподілений у просторі програмно-апаратний комплекс, призначений для виконання функції обробки, зберігання i розповсюдження інформації шляхом надання інформаційних послуг споживачам інформації [1]. У зв'язку з цим, важливе значення набувають такі показники продуктивності функціонування ЦОД, як його пропускна спроможність та час відгуку. Серед багатьох факторів, на які впливають зазначені показники, важливим $\epsilon$ забезпечення доступності інформації.

Під доступністю інформації розуміється стан, за якого користувачі, що мають права доступу до інформації, можуть реалізовувати ix безперешкодно. До прав доступу відносяться: право на читання, зміну, зберігання, копіювання, знищення інформації.

Для організації безперешкодного доступу до інформації у ЦОД використовується модель багаторівневого зберігання даних, яка передбачає ієрархічний поділ інформації залежно від рівня іiі затребуваності користувачами. Крім того, використовується система резервного копіювання і відновлення даних - програмноапаратний комплекс, який дає змогу не допустити втрату інформації у разі збоїв у роботі обладнання, а також унаслідок помилок програмних засобів або користувачів. Це гарантує повне відновлення інформації в найкоротші терміни, знижує час простою ЦОД і супутні матеріальні збитки.

Технологічна інфраструктура ЦОД реалізується за допомогою комутованої мережі, що зв'язує між собою різні компоненти ЦОД: програми, сервери, спеціалізовані пристрої, системи зберігання і користувачів. До того ж у мережевій архітектурі ЦОД виділяється чотири ключових компоненти:

мережа високопродуктивних обчислень для забезпечення взаємодії серверів у високопродуктивних кластерах;

мережа зберігання даних для консолідації ресурсів пам'яті, щоб вони могли розподілятися $\mathrm{i}$ використовуватися більш ефективно;

мережа взаємозв'язку з резервним ЦОД, що з'єднує основний і резервний ЦОД по оптичним або традиційним мережам та забезпечує реплікацію даних;

мережа доступу, що надає безпечний доступ для користувачів.

Для забезпечення доступності інформації необхідним $\epsilon$ апріорне знання показників ефективності утворюючих його мереж. Одним із суттєвих показників ефективності, який впливає на доступність інформації в ЦОД $\epsilon$ продуктивність його розподіленої інформаційної системи (РIC).

Існуюча практика оцінювання продуктивності РІС ЦОД носить лише орієнтовний характер. Найбільш раціональним підходом щодо одержання розрахунків продуктивності РІС ЦОД $є$ застосування прогностичних моделей. Знаючи прогноз продуктивності РIC можна передбачити поведінку системи у різних 
умовах функціонування та забезпечення доступності інформації ЦОД.

Постійне зростання обчислювальних можливостей апаратних платформ та нерівномірність оновлення обчислювальної техніки у Збройних Силах України призводить до того, що матеріальну основу РІC, що взаємодіятимуть у ЦОД, сьогодні складають різнорідні за потужністю апаратні засоби. Робота цих засобів має бути узгоджена 3 урахуванням продуктивності та індивідуальних особливостей побудови програмного забезпечення.

Крім того, до особливостей застосування зазначених РІС ЦОД військового призначення відносяться:

багаторівневий ієрархічний характер архітектури; відсутність загального централізованого управління обчислювальним процесом; відсутність єдиного скоординованого часу в системі; наявність конфліктів і ресурсів, які спільно використовуються.

У зв'язку з цим актуальною $є$ загальна проблема прогнозування продуктивності PIC ЦОД та оцінювання доступності інформації 3 урахуванням технічних параметрів складових елементів ЦОД.

Аналіз останніх досліджень та публікацій. Переважна більшість теорій побудови розподілених інформаційних систем, що складають обчислювальну мережу ЦОД, не охоплюють всі зазначені особливості комплексно. Проблема визначення продуктивності РІC ЦОД пов'язується 3 побудовою математичних моделей, які б дали змогу варіювати простір ознак доступності інформації на основі прогностичних коефіцієнтів. Один з таких підходів базується на використанні калібрувального методу [2]. Водночас, запропонована модель достатньо складно масштабується на випадок опису великих систем, які складаються із сотень i тисяч вузлів.

Традиційні моделі для паралельних систем передбачають постійний склад обчислювального простору i не застосовуються для опису розподілених систем, тому продуктивність розподілених додатків описується, як правило, на якісному рівні. Останнім часом з'явились та одержали розвиток технології розподілених обчислень [3], які застосовуються за участі різнорідних обчислювальних ресурсів. Особливістю таких PIC $\epsilon$ неоднорідна та динамічно-змінна структура ресурсів - обчислювальні вузли можуть підключатися до системи та виходити 3 неї у будь-який момент протягом роботи системи. Водночас, хоча модель у [3] і враховує деякі особливості РІC, проте не дає змоги кількісно оцінювати загальну продуктивність такої системи.

У роботі [4] запропоновано підхід до оцінювання доступності інформації на основі продуктивності розподілених обчислювальних систем, до складу яких входять вузли різної потужності. При цьому вузли беруть участь в обчисленнях згідно 3 певним розкладом функцією, яка приймає значення 1 у моменти, коли вузол виділяється для обчислень, і 0 у протилежному випадку. Обмеженість моделі [4] визначається необхідністю апріорного знання розкладу роботи системи. У [5] для таких систем “3 розкладом" авторами пропонується методика аналізу продуктивності, заснована на порівнянні роботи системи 3 еталонною гіпотетичною системою. Варіювання еталонної системи дає змогу одержати кількісні оцінки різних характеристик, що і було реалізовано на практиці у системі BNB-Grid [6]. Проте такий підхід не дає змоги обчислювати кількісні характеристики системи апріорно, на основі аналітичних розрахунків.

у [7] пропонується оцінювати продуктивність PIC із сервіс-орієнтованою архітектурою через урахування залежності пропускної здатності та обсягу буферів базової телекомунікаційної мережі від ймовірності втрати запитів в системі. Визначення параметрів здійснюється шляхом моделювання за допомогою ієрархічних кольорових мереж Петрі, хоча запропонований апарат не дає можливості здійснювати алгоритмічний аналіз роботи мережі.

Найбільш близькими щодо вирішення проблеми побудови моделі розподіленого процесу функціонування PIC у теоретичному плані $є$ роботи в області теорії розподілених обчислень та паралельних процесів. Так, у [8] алгоритми оцінювання базуються на оцінюванні часу виконання задач, який залежить від багатьох факторів - архітектури системи, середовища паралельних обчислень, властивостей програмних засобів, які застосовуються. У [9] основний акцент робиться на оцінюванні властивостей потоків інформації та впливу на загальну продуктивність системи. У [10] наведено порівняльний аналіз технологій оцінювання продуктивності, які використовуються у 
сучасних парадигмах розподілених обчислень. Відмічається, що, хоча кожна 3 цих парадигм має власні засоби оцінки продуктивності, всі вони $є$ постфакторними i потребують достатньої статистики роботи системи. До того ж апріорне оцінювання продуктивності залишається проблемним питанням.

Крім того, у цих роботах не враховуються індивідуальні апаратні особливості елементів системи, поведінка у процесі функціонування та внутрішні комунікаційні можливості елементів системи.

Отже, залишаються нерозв'язаними питання комплексного оцінювання продуктивності РІС з урахуванням зазначених раніше особливостей побудови: багаторівневої архітектури, відсутності централізації та координації часу, наявності конфліктів та ресурсів, які спільно використовуються.

Метою статті $\epsilon$ розроблення підходу щодо забезпечення доступності інформації центру обробки даних на основі оцінювання балансу продуктивності системи.

Виклад основного матеріалу. Для досягнення поставленої мети необхідно:

визначити структуру та розробити опис процесу функціонування інформаційної системи, призначеної для розподіленого виконання завдань;

розробити підхід щодо оцінювання основних видів продуктивності РІС ЦОД;

визначити основні показники продуктивності та порядок їх обчислення;

здійснити моделювання РIC за основними показниками продуктивності.

Структура та прочес функиіонування розподіленої інформаиійної системи ЦОД. Уже достатньо тривалий час робота складних інформаційних систем 3 розподіленою архітектурою описується моделлю, яка дає змогу представити таку систему, як сукупність взаємодіючих автономних сутностей інформаційного простору. Процес функціонування РIC, що працює у складі ЦОД, визначає взаємодія процесів роботи програмних об'єктів (агентів) $A_{i, j}, i=\overline{1, m}, j=\overline{1, n_{i}}, \quad$ які $\quad$ працюють під керівництвом контейнерів $K_{i, j}, i=\overline{1, m}, j=\overline{1, n_{i}}, 3$ операторами $O_{i, j}$ та логічним середовищем платформи існування $\Pi_{i, j}$ у деякому фізичному середовищі розподіленої інформаційної системи. Сукупність $\Pi_{i, j}, O_{i, j}, A_{i, j}, K_{i, j} \quad$ утворює послідовного виконавця $B_{i, j}$. Так само сукупність послідовних виконавців утворює розподіленого виконавця [11].

Схемне уявлення про цю взаємодію можна описати так. Кожен оператор $O_{i, j}$ виконує певну послідовність дій, які визначені регламентом його роботи. До того ж він працює у програмному середовищі, встановленому на його платформі $\Pi_{i, j}$ (програмне забезпечення ЦОД, розподілені додатки та ін.). Послідовність дій виконавця складається 3 окремих кроків $S_{i, j, k}, i=\overline{1, m}, j=\overline{1, n_{i}} k=\overline{1, K_{i, j}}$, де $K_{i, j}-$ загальна кількість кроків $j$-го виконавця $i$-го рівня, які фіксуються логічним середовищем платформи та $є$ видимими для його агента $A_{i, j}$.

На основі дій оператора належний йому агент визначає логічну послідовність своїх дій. Частина цих дій - звернення та передача інформації до інших агентів, а інша частина до оператора. Звернення до агентів та оператора супроводжуються передаванням повідомлень відповідного типу. Такий підхід дає змогу наочно подати роботу системи у вигляді мережевого графіка, кожен крок якого надалі може бути оціненим 3 погляду його тривалості. Сукупність часових відрізків, які відповідатимуть певним крокам, 3 урахуванням простоїв елементів i буде визначати загальну тривалість роботи системи. Відношення тривалості роботи до загального часу застосування і складає суть поняття продуктивності системи.

Основні параметри продуктивності розподіленої інформачійної системи. Для забезпечення можливості оцінювання алгоритмічного та кількісного аспектів функціонування РІС скористаємось підходом [12-14], де зазначається, що основні види продуктивності можуть бути отримані на основі часової діаграми роботи комп'ютерної системи. Тому метою є отримання часової діаграми роботи системи. Цю діаграму можна описати за допомогою часового профілю.

Часовим профілем роботи розподіленої системи $C S$ назвемо вектор-функцію $G(t)=\left[g_{1}(t), g_{2}(t), \ldots, g_{n}(t)\right], i=\overline{1, n}, \quad$ де $g_{1}(t)-$ часовий профіль послідовного виконавця $S E_{i} \in C E$.

\section{Часовим}

профілем

послідовного виконавияя $S E_{i}$ назвемо однозначну функцію $g_{1}(t)$, визначену на $R, 3$ областю значень - 
множина кортежів виду $\left\langle p, s, q, a_{i}\right\rangle$, де $p \in P$ - процес, $s \in S(p)$ - крок, $q \in c x(s)$ дія, $a_{i} \in w\left(q_{i}\right) \quad$ - атомарний процес послідовного виконавця $S E_{i}$. Завдання побудови $G(t)$ для системи $C S$ розбивається на два етапи:

$$
c x(s)=\langle\text { формування об' єкта, активаџія, обчислення,... }\rangle,
$$

які визначають функціональність агентів у системі. Зі свого боку, кожна дія складається 3 множини атомарних процесів, що виконуються машиною під час реалізації дій $w\left(q_{i}\right)=\langle$ cmapm, запит,..., cmon, nауза $\rangle$.

Кожен атомарний процес має деяку тривалістю його виконання, сумарна тривалість сукупності атомарних процесів i визначатиме загальний час виконання програми під час розв'язання певних задач. Знаючи часовий профіль поведінки системи, можна отримати оцінки різних видів продуктивності, а також вивести співвідношення, що зв'язують основні форми продуктивності 3 різними кількісними характеристиками функціонування системи.

Нехай дано розподілену систему $C S$, яка складається $3 Q$ послідовних виконавців. Введемо змінні, що характеризують функціонування $C S$ :

T - тривалість періоду функціонування $C S$ за астрономічним часом;

J - число завдань, виконаних $C S$ за період спостереження.

Завдання можна розуміти як виконання операції, функції, кроку, команди тощо.

Позначимо:

$$
X=J / T-\text { пропускна спроможність }
$$

системи $C S$;

$$
U_{i} \text { - кількість астрономічного часу, }
$$

протягом якого і-й послідовний виконавець 3 $C S$, був зайнятий виконанням завдання з $\mathrm{J}$;

$$
W_{i}=U_{i} / T-\text { завантаження }
$$

виконавця; для кожного $S E_{i}$ визначити послідовність виконуваних ним дій;

для кожної дії визначити час, необхідний цьому $S E_{i}$ на іiі виконання.

Кожен 3 кроків передбачає певну сукупність операцій у системі

$$
N_{i} \text { - загальна кількість дій (дія } \epsilon
$$

складовою частиною завдання), виконаних $i$-м послідовним виконавцем протягом періоду $T$.

$$
P w_{i}=U_{i} / N_{i} \text { - середній час дії } i \text {-го }
$$

послідовного виконавця (це потужність виконавця, яка залежить від продуктивності його апаратних засобів та організації процесу);

$$
E n_{i}=N_{i} / J-\text { середнє число дій } i \text {-го }
$$

об'єкта на одне завдання з $J$.

$\mathrm{У}$ цих позначеннях справедливим буде таке твердження.

Пропускна спроможність $i$-го послідовного виконавця $i=\overline{1, Q}$ може бути визначена за співвідношенням $X_{i}=\frac{W_{i}}{P w_{i} E n_{i}}$.

Приклад залежності пропускної спроможності $X$ від потужності $P w_{i}$ та середнього числа дій $E n_{i}$ при $W_{i}=1$ наведено на рис. 1.

Як бачимо, збільшення числа дій на одну задачу $E n_{i}$, або зменшення потужності (збільшення часу $P w_{i}$ ), однозначно призводять до зменшення пропускної спроможності виконавця.

Також визначимо співвідношення між потужністю послідовного виконавця $P w_{i}$, числом $N_{i}$ виконуваних ним дій при рішенні задачі і відношенням часу обчислення $U_{i}$ до часу обміну $T o_{i}: \lambda_{i}=T o_{i} / U_{i}$, де $T \geq T o_{i}+U_{i}$. 


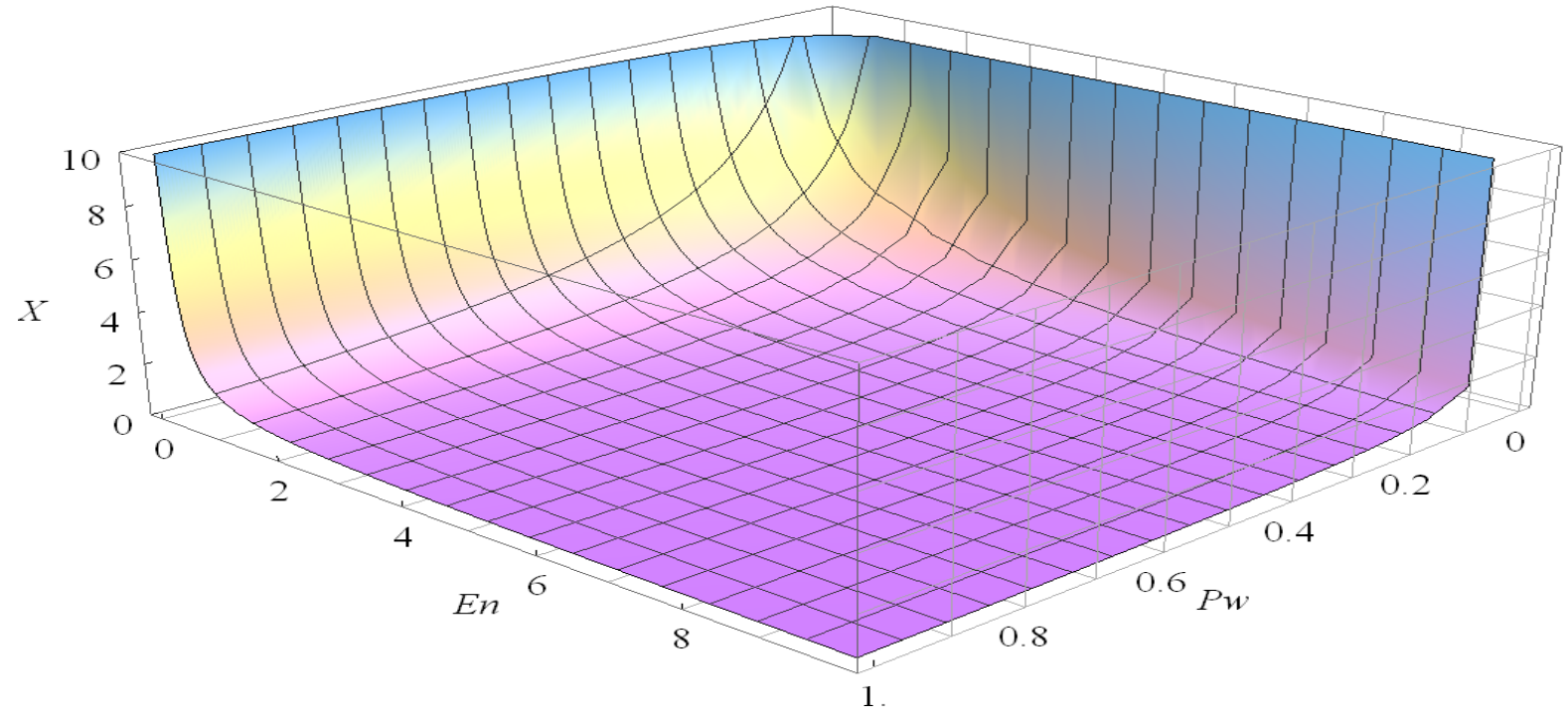

Рис. 1. Залежність пропускної спроможності системи від потужності виконавця та середнього числа дій на одне завдання

Тепер завдання щодо поділу задач на розподіленій системі $C S$ можна сформулювати так:

1. Дано: $N$ - загальна кількість дій, які треба виконати за час $T$;

2. Треба так розподілити ці дії між $Q$ виконавцями щоб: $\frac{T}{\left(1+\lambda_{i}\right) N_{i}} \geq P w_{i} \quad$ або $\frac{T}{P w_{i}} \geq N_{i}\left(\lambda_{i}+1\right), \quad$ де $\sum_{i=1}^{m} N_{i}=N, \quad \lambda_{i}=\frac{T o_{i}}{U_{i}} \quad$ i $T \geq T o_{i}+U_{i}$.

Знаючи часовий профіль $G(t)$, можна отримати набір операційних змінних $W, N_{i}, J$ і $T$. Візьмемо за завдання виконання процесу у системі, а як дію - атомарний процес послідовного виконавця. Тоді:

$$
J=\sum_{i=1}^{Q} J_{i}, \quad \text { де } \quad j_{i}=\sum_{t_{k} \in T} g\left(t_{k}\right) \quad\left(t_{k} \quad-\right.
$$

момент закінчення процесу, наприклад, звернення до Stop в профілі $g_{i}$ ).

$$
U_{i}=\sum_{p \in P} \int_{0}^{T} \chi_{p}\left(t_{k}\right) d t, \quad \text { де } \quad \chi_{p}(t) \quad-
$$

характеристична функція кроку процесу $p$, тобто $\chi_{p}(t)=1$ якщо $g_{i}(t)=\langle p . s . q . a\rangle, \quad$ або $\chi_{p}(t)=0$ у протилежному випадку.

$$
N_{i}=\sum_{p \in P} \int_{0}^{T} \delta_{i}(t) d t, \text { де } \delta_{i}(t)-\text { функція, яка }
$$

приймає значення 1 у момент зміни значення $g_{i}(t)=1$ і дорівнює 0 в решту моментів часу.
Наступним важливим видом продуктивності є час відгуку системи. Нехай на $C S$ розташовано $N$ агентів, до яких надходять запити. У якості завдання візьмемо виконання $j$-м агентом $(j=\overline{1, N})$ запиту. Припускаємо, що $N$ не змінюється протягом періоду спостереження. Введемо такі позначення:

$J$ - число запитів, виконаних за період спостереження $T$;

$J^{\prime}$ - число завдань, що надійшли в систему за період спостереження;

$$
\begin{aligned}
& r(k) \text { - час корисної роботи } k \text {-го агента; } \\
& z(k)=T, r(k) \text { - час “простою” } k \text {-го }
\end{aligned}
$$
агента.

Середній час виконання завдання можна виразити як $R=\frac{1}{J} \sum_{k=1}^{N} r(k)$. Середній час очікування запиту можна виразити як $Z=\frac{1}{J^{\prime}} \sum_{k=1}^{N}(T-r(k))$.

Взаємозв'язок між часом відгуку i пропускною спроможністю системи може бути визначено на основі співвідношення: $R=\frac{N}{X}-Z \frac{J^{\prime}}{J}$, що може бути доведено наступним чином: $\forall k \mid k=1 . . . N \Rightarrow z(k)+r(k)=T . \quad$ Звідси $\sum_{k=1}^{N} z(k)+\sum_{k=1}^{N} r(k)=N T$. У разі, коли $C S-$ послідовний виконавець, $\sum_{k=1}^{N} r(k) \leq T$. Далі 
$\frac{1}{J} \sum_{k=1}^{N} z(k)+\frac{1}{J} \sum_{k=1}^{N} r(k)=\frac{N T}{J}$,

або

використовуючи раніше введені позначення, можна записати $Z \frac{J^{\prime}}{J}+R=\frac{N}{X}, \quad$ звідки отримуємо підтвердження істинності $R=\frac{N}{X}-Z \frac{J^{\prime}}{J}$.

Використовуючи раніше введене визначення пропускної спроможності, отримуємо: $\quad R=\frac{N \cdot P w_{i} \cdot E n_{i}}{W_{i}}-Z \frac{J^{\prime} Z}{J_{i}}$.

у разі $N<<J: R=\frac{N \cdot P w_{i} \cdot E n_{i}}{W_{i}}-Z$.

Приклад залежності часу відгуку $R$ від $X$ та відношення $J^{\prime} / J$ для $N=5$ та $Z=2$ наведено на рис. 2. Як бачимо, за умови збільшення пропускної спроможності системи $X$ час відгуку системи зменшується, досягаючи 0 , коли $\frac{N}{X}=Z \frac{J^{\prime}}{J}$.

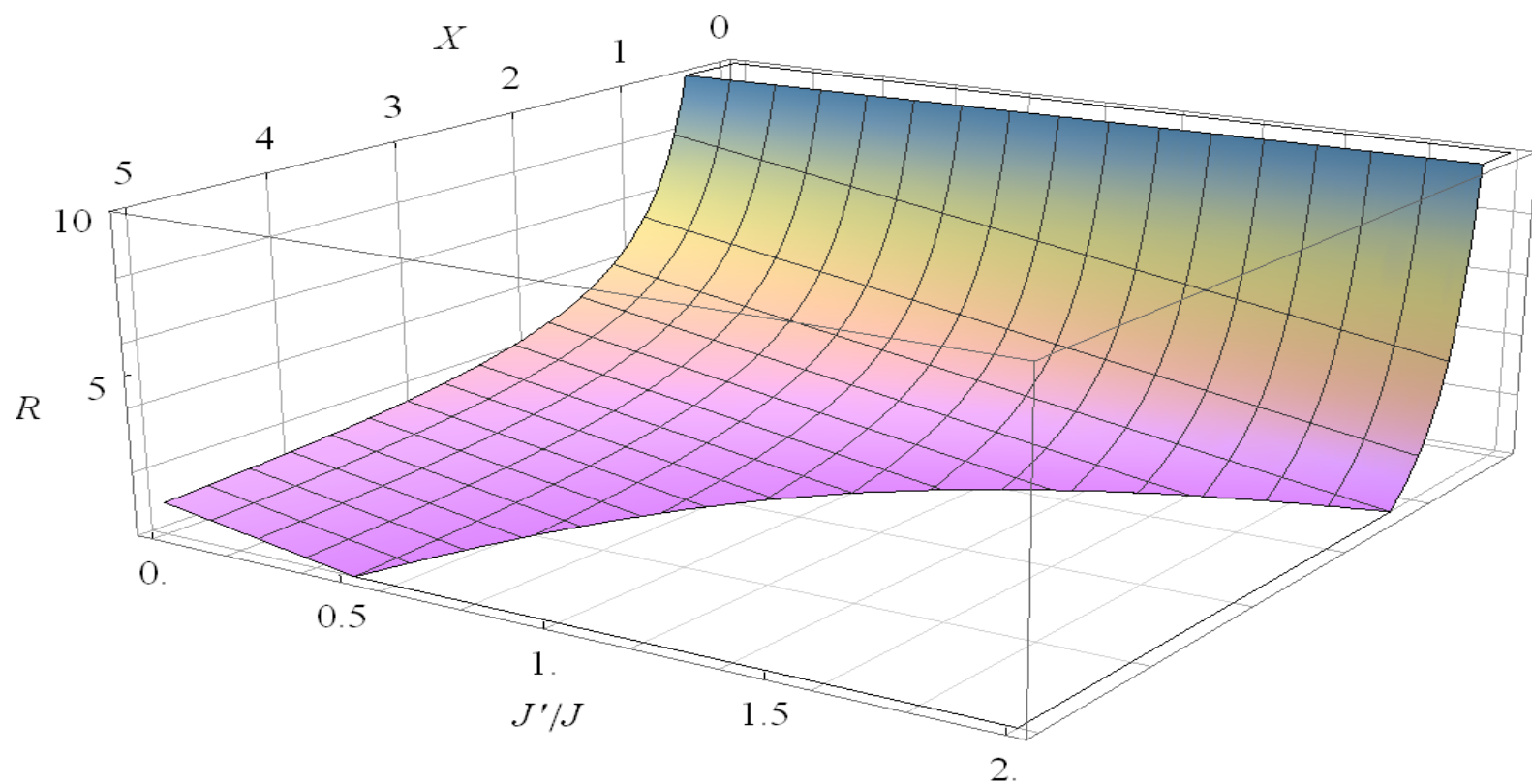

Рис. 2. Залежність часу відгуку системи від пропускної спроможності та відносної кількості невиконаних заявок

На основі двох розглянутих видів продуктивності визначимо характеристики, які описують використання ресурсів (пам'яті) у системі. Нехай функція $\operatorname{Stg}(p, t)$ визначає кількість одиниць пам'яті, займаної процесом $p$ у момент $t$. Позначимо: $m_{t}(p)=\int_{0}^{T} \operatorname{Stg}(p, t) d t \quad$ і $\operatorname{Str}=\frac{1}{J} \sum_{p}^{N} m_{t}(p)$, де $N$ - число агентів, які були присутні у момент $t=0$, тобто не враховуємо динаміки функціонування агентів, а сума береться за

$$
M=\frac{1}{T} \int_{0}^{T} \sum_{p=1}^{N} S t g(p, t) d t=\frac{J}{T}\left(\frac{1}{J} \sum_{p=1}^{N} \int_{0}^{T} S t g(p, t) d t\right)=\frac{J}{T}\left(\frac{1}{J} \sum_{p=1}^{N} m_{t}(p) \cdot m_{t}\left(p_{k}\right)\right) .
$$

Звідки отримуємо $M=X \cdot S t r$. всіма $p$ в системі. Тоді кількість пам'яті, яка використовується в системі у момент $t$, дорівнює $m(t)=\sum_{p=1}^{N} \operatorname{Stg}(p, t)$

У цих позначеннях середня кількість пам'яті, що використовується у системі, можна виразити як $M=\frac{1}{T} \int_{0}^{T} m(t) d t$, або, використовуючи вираз для $m(t)$ : 
Використовуючи формулу часу відгуку i підставивши в неї вираз для $X$, отримаємо $R=\frac{N \cdot S t r}{M}-Z$.

Наведені співвідношення дають змогу кількісно оцінити параметри розподілених інформаційних систем та синтезувати системи iз заданими параметрами пропускною спроможністю і часом відгуку.

Надалі, для забезпечення безперебійної роботи усієї розподіленої системи ЦОД необхідно узгодити параметри пропускної спроможності та часу відгуку окремих елементів системи між собою, що $\mathrm{i}$ забезпечить доступність інформації у ЦОД.

Таким чином, реалізується можливість апріорного формування структури РІС ЦОД з завчасно заданими параметрами щодо доступності інформації.

Аналіз результатів застосування методики. Застосування часових профілів для розв'язання задачі аналізу продуктивності розподіленої інформаційної системи дає змогу вирішити проблему апріорної оцінки параметрів проєктованих розподілених систем 3 метою розгортання на різнорідних апаратних платформах. Як видно 3 проведеного дослідження, вихідними даними для обчислень $\epsilon$ часові показники виконання елементарних операцій під час виконання завдань системою. Зазначені показники безпосередньо залежать від технічних характеристик апаратних платформ виконавців і напряму визначають параметри продуктивності системи загалом. Точність визначення продуктивності системи залежатиме від точності визначення часу виконання окремих атомарних операцій.

Знаючи часовий профіль роботи системи, можна отримати основні характеристики продуктивності - пропускну спроможність та час відгуку. Отримані співвідношення дають змогу також оцінити мінімальний час обчислень, необхідний для одного інформаційного обміну з урахуванням ліміту загального часу розв'язання задачі. До того ж встановлено аналітичний зв'язок між технічною продуктивністю виконавця, числом виконуваних ним дій під час роботи програми та часом обміну і обчислення. Застосування запропонованої методики $\epsilon$ особливо необхідним на ранніх етапах розробки PIC для оптимального проєктування програмного забезпечення систем.

Створена модель описує динаміку взаємодії процесів прикладних програм 3 функціонуванням фізичного середовища платформи виконання. У ній відображені як ієрархічна структура обчислювальної системи, так і розподілений характер логічного та фізичного середовища. До того ж поведінка процесу виконання програми розподіленим виконавцем не залежить від часу роботи послідовних виконавців, які здатні функціонувати автономно один від одного.

Загальна задача аналізу продуктивності подається у математичній формі задачі побудови часового профілю - вектор функції, яка описує часову діаграму функціонування розподіленої обчислювальної системи. Окрім можливості оцінювання основних видів продуктивності (пропускної здатності та часу відгуку) запропонований підхід дає змогу оцінювати також i інші показники ефективності: мінімальний час обчислень, які припадають на один обмін при заданому загальному часі обчислень; співвідношення часу обміну та часу обчислень та ін.

Переваги проведеного дослідження полягають у простоті та доступності запропонованого підходу щодо визначення продуктивності розподілених систем на основі побудови часових профілів. Адже для побудови часових діаграм необхідним є лише знання часу виконання окремих елементарних операцій, після чого, завдяки простим арифметичним операціям, обчислюється загальний час роботи виконавця та співвідноситься 3 загальним часом роботи системи. Застосування наведених співвідношень $є$ особливо корисним на ранніх етапах розробки а також при перевірці коректності моделей обчислювальних систем.

Обчислення параметрів апаратних засобів РIC на основі знання часових проміжків виконання елементарних операцій послідовними виконавцями дозволяе уникнути основних недоліків, притаманних класичним підходам щодо побудови та оцінювання продуктивності PIC.

Так, запропонована модель не потребує визначення прогностичних коефіцієнтів, необхідних для реалізації підходу на основі використання калібрувального методу [2]. До того ж, запропонована модель може бути масштабована на достатньо значне число виконавців, кількість яких обмежується лише наявністю первинної інформації щодо параметрів функціонування.

Крім того, запропонована модель добре узгоджується також i 3 парадигмою розподілених обчислень довготривалих задач 3 непостійним складом виконавців [3]. У такому випадку змінним параметром $\epsilon$ 
кількість послідовних виконавців та їх ієрархічна підпорядкованість розподіленому виконавцеві.

На відміну від моделей оцінювання продуктивності у системах, які працюють за розкладом $[4,5]$, запропонована модель не потребує апріорного знання розкладу роботи та визначення еталонних параметрів процесу. Водночас, модель все ж таки потребує знання тривалості елементарних операцій, що складають суть завдання, яке виконується.

Порівняння запропонованого підходу 3 моделюванням за допомогою ієрархічних кольорових мереж Петрі [7] свідчить про відсутність необхідності апріорного достатньо складного обчислення ймовірності втрати запитів в системі. А, порівняно з технологіями сучасних розподілених обчислень (Cloud, Jungle and Fog Computing) [10] немае необхідності збору достатньої кількості статистики роботи системи для ii постфакторного оцінювання.

Крім того, запропонований підхід враховує індивідуальні апаратні особливості елементів системи, поведінку у процесі функціонування та внутрішні комунікаційні можливості окремих елементів.

Одним 3 проблемних питань застосування моделі процесу функціонування на основі часових профілів $€$ необхідність чіткого знання для кожного з виконавців:

послідовності дій, які виконуються;

часу виконання елементарних операцій, які складають кожну дію.

Крім того, необхідним також є знання щодо перерозподілу завдань (передачі управління), які виконуються послідовними виконавцями, що утворюють певного розподіленого виконавця.

У разі постійного розширенні кола завдань, ускладненні процедур їх узгодження між виконавцями, призводить до росту обчислювальної складності у геометричній прогресії i слугуватиме обмежуючим фактором подальшого застосування моделі. Виходом 3 такої ситуації може бути узагальнення (агрегація) окремих типових блоків виконавців та завдань, які ними виконуються.

Напрямом подальших досліджень у рамках запропонованого підходу можуть бути моделі та методи функціонування розподілених систем та паралельних обчислень з урахуванням алгоритмічних та структурних особливостей фізичного та логічного середовищ РІС ЦОД. Апріорне знання параметрів функціонування дасть змогу не лише оцінювати продуктивність РІC, а й створити умови для розроблення протоколів взаємного функціонування елементів PIC, перерозподілу завдань, оптимізації управління тощо.

Одним 3 проблемних питань, які потребують окремого дослідження, є дослідження впливу технічних параметрів обчислювальної системи на параметри продуктивності. Адже, архітектура та параметри обладнання (процесор, пам'ять) можуть суттєво змінювати часовий профіль виконання одних i тих завдань. Відтак, зазначені аспекти потребують окремого (індивідуального) врахування.

\section{Висновки:}

1. Одним 3 визначальних факторів впливу на доступність інформації у розподіленій системі $є$ забезпечення балансу продуктивності окремих іiі елементів. Для цього процес функціонування розподіленої інформаційної системи доцільно подати як взаємодію процесів роботи програмних об'єктів (агентів) 3 операторами та логічним середовищем платформи існування у деякому фізичному середовищі системи. До того ж сукупність платформ, операторів, агентів та відповідних контейнерів утворює послідовного виконавця. Зі свого боку, сукупність послідовних виконавців утворює розподіленого виконавця. Послідовність дій виконавця складається 3 окремих кроків, які фіксуються логічним середовищем платформи, що дозволяє побудувати часовий профіль його роботи та забезпечити баланс продуктивності складових елементів.

2. Побудова часових профілів для виконавців дає можливість оцінювати основні види продуктивності розподіленої інформаційної системи. Завдання побудови часового профілю виконується у два етапи: для кожного послідовного виконавця визначається послідовність дій, які ним виконуються; для кожної дії визначається час, необхідний даному виконавцю на іiі виконання. Часовий профіль будується на основі знання часу виконання атомарних операцій.

3. За основні показники, за якими оцінюється продуктивність розподіленої інформаційної системи, пропонується використовувати пропускну спроможність послідовного виконавця та час відгуку системи. На основі зазначених показників $\epsilon$ можливість визначати мінімальний час обчислення, середній час виконання завдань та середній час очікування запиту. Таким 
чином утворюється система показників продуктивності інформаційної системи, яка дає змогу здійснювати як алгоритмічний, так i кількісний аналіз процесів іiї функціонування.

$$
\text { 4. Моделювання розподіленої }
$$

інформаційної системи за основними показниками продуктивності підтверджує істинність запропонованого підходу i дає змогу наглядно оцінити зв'язок між основними показниками продуктивності, баланс яких i $\epsilon$ основою забезпечення доступності інформації. Так, дослідження залежності пропускної спроможності від потужності виконавця та середнього числа дій на одне завдання показують, що збільшення числа дій на одне завдання, або зменшення потужності, однозначно призводять до зменшення пропускної спроможності виконавця. Зі свого боку, збільшення пропускної спроможності призводить до зменшення часу відгуку системи.

Напрямом подальших досліджень у цій сфері може бути чимало питань теоретичного обгрунтування параметрів процесів функціонування елементів розподілених інформаційних систем та їх вплив на ключові характеристики інформаційної безпеки - конфіденційність, цілісність та доступність.

\section{СПИСОК ВИКОРИСТАНОЇ ЛІТЕРАТУРИ}

1. Кірпічніков Ю. А., Кондратенко Ю. В., Головченко О. В. Оцінка технологічних рішень щодо створення програмно-апаратної платформи інформаційної інфраструктури Міністерства оборони України. Збірник наукових пращь Центру воєнно-стратегічних досліджень Національного університету оборони України імені Івана Черняховського. Київ, 2016. № 2. С. 39-43.

2. Хошаба О.М. Изучение метода калибровки как важного составляющего теории производительности вычислительных систем. Інформаційні технології в освіті, науці $і$ технічі : зб. тез доп. III Міжнародної наук.-практ. конф. Черкаси, 2016. С. 52-54.

3. Sukhoroslov O. V., Nazarenko A. M. Comparative study of scheduling algorithms for distributed computing environments. Program Systems: Theory and Applications. 2017. Vol. 8. Issue 1. P. 63-81.

4. Афанасьев А. П., Посипкін М. А., Хританков А. С. Аналитическая модель оценки производительности распределенных систем. Программные продукты $и$ системы. 2009. № 4. С. 60-64.

5. Хританков А. С. Оценка эффективности распределенных систем при решении задач переменного размера. Научно-технический вестник информационных технологий, механики и оптики. 2010. № 2 (66). С. 66-71.

6. Посипкін М. А. Методы и распределенная программная инфраструктура для численного решения задачи поиска молекулярных кластеров с минимальной энергией. Информационные технологии. Вестник Нижегородского университета им. Н.И. Лобачевского. Нижегородск, 2010. № 1. С. 210-219.

7. Kovalenko T. N. Analysis of Productivity of Distributed Systems with Service Oriented Architecture under Conditions of Limited Link and Buffer Resources of Telecommunication Network. Telecommunications Problems. 2012. № 1 (6). P. 3-11.

8. Rauber Th., Runger G. Parallel Programming for Multicore and Cluster Systems. Springer, XIII. 2013. $516 \mathrm{p}$.

9. Kahanwal, B. Towards High Performance Computing (HPC) Through Parallel Programming Paradigms and Their Principles. International Journal of Programming Languages and Applications (IJPLA). 2014. Vol. 4. No. 1. P. 45-55.

10. Hajibaba M., Gorgin S. A Review on Modern Distributed Computing Paradigms: Cloud Computing, Jungle Computing and Fog Computing. Journal of Computing and Information Technology. 2014. CIT 22, 2. P. $69-84$.

11. Савченко В.А. Визначення продуктивності мультиагентної системи підтримки прийняття рішень на основі побудови часового профілю. Збірник наукових праџь Інституту проблем моделювання в енергетиці. Моделювання та інформаційні технологї. Київ, 2011. № 59. С.67-72.

12. Смелянский Р. Л. Модель функционирования распределенной вычислительной системы с временем. Программирование. 2013. № 5. С. 22 ?234.

13. Smelianskii R.L. Automated Control Systems Networks. Computer Networks. 2011. Vol. 2. 240 p.

14. Savchenko V., Matsko O., Vorobiova V., Kizyak Y, Duhanets V. Assessment of Performance of a Distributed Information System Based on Time Profil. Eastern European Journal of Enterprise Technologies. 2017. № 6/2 (90). C. 41-54.

Стаття надійшла до редакційної колегії 21.10.2019

\section{Ensuring the availability of information in the military data processing center based on the balance of system performance}

\section{Annotation}

Informatization of the Armed Forces of Ukraine provides for the creation of an information infrastructure and the introduction of elements of the Unified Automated Control System of the Armed Forces of Ukraine. Data processing centers (DPC) should become the hardware and software basis and the main component of the information infrastructure of the Ministry of Defense of Ukraine. In this regard, such indicators of the performance of the functioning of the data center as its throughput and response time become important. Among the many factors influencing these indicators, ensuring the availability of information is important. 
The availability of information is understood as a state in which users who have access rights to information can exercise them freely. Access rights include: the right to read, modify, store, copy, destroy information.

The current practice of evaluating the performance of a distributed information system (RIS) of a data center is only indicative. The most rational approach to calculating the performance of RIS data centers is the use of predictive models. Knowing the forecast of the RIS performance, it is possible to predict the behavior of the system in various conditions of operation and ensuring the availability of data center information.

The purpose of the article is to develop an approach to ensure the availability of data center information based on an assessment of the balance of system performance.

Modeling a distributed information system in terms of the main performance indicators confirms the truth of the proposed approach and allows you to visually assess the relationship between the main performance indicators, the balance of which is the basis for ensuring the availability of information.

Keywords: data processing center; distributed information system; hour profile; consistent performer; bandwidth; system response time. 